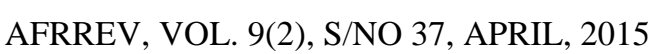 \\ African Research Review
}

An International Multidisciplinary Journal, Ethiopia

Vol. 9(2), Serial No. 37, April, 2015:59-77

ISSN 1994-9057 (Print) ISSN 2070-0083 (Online)

DOI: http://dx.doi.org/10.4314/afrrev.v9i2.5

\section{Fifteen Years of Democracy, 1999-2014: Reflections on Nigeria's Quest for National Integration}

\author{
Egbefo, Omolumen Dawood \\ Department of History and International Studies \\ IBB University Lapai, Niger State, Nigeria \\ E-mail: dawoodamirah@yahoo.com \\ M-Phone: 08076709828, 08109492681
}

\begin{abstract}
This paper examined fifteen years of Nigerian democracy and its reflection on national integration, which is one of the basic dividends expected of any democratic system. The paper aims to bring to the fore why and how Nigerian democracy since 1999 to date is yet to put in place integrative mechanism for its divergent but dynamic nationalities to nationhood. Few works exist about Nigerian Democracy but its effort on national integration is scanty. Thus this paper is timely and relevant and asks for further research. The paper examines major contending issues affecting the Nigerian democracy, such as ethnicity, state creation, indigenes/settlers dichotomy, federal character principles, corruption, poverty, bad governance among others. The research method was majorly secondary data collection. Then, the paper proffered some ways forward and a conclusion by positing that after fifteen years promotion of good governance, social justice, economic development and some other structures, Nigerian democracy should have by now integrated the divergent nationalities into nationhood because it is achievable as experienced in Canada, Germany, America, Italy among others.
\end{abstract}




\section{Introduction}

The important occasion of the fifteenth anniversary of Nigerian democracy is not just timely but necessary for reflection on the past fifteen years of the nation's democracy. Nigeria's democracy is truly at a crossroads. Although there has been much progress in the years since the 1999 political transition, there are also deepseated problems of structure, institutional weakness, performance that are jeopardizing the democratic experiment and the nation quest for national integration. Nigeria's political class is fragmented and contentious, its institutions largely feeble or dysfunctional. Basic public goods are lacking, the vast majority of the population is impoverished, and an epidemic of social violence has undermined security throughout the federation. Ethnic, religious, and regional polarization has arguably worsened in recent years, creating further uncertainties about a fragile national compact.

However, it is pertinent to note that Nigeria is now enjoying the longest period of civilian rule since independence in 1960. The first civilian republic ended in a military coup in 1966, ushering in a devastating civil war and several more military governments. In fact, during the thirty three years from 1966 until the Fourth Republic came into being in 1999, civilians only governed for four short years. Historically, therefore, the dearth of democratic experience has created enormous challenges to institutionalizing democracy and national integration for national development in Nigeria.

When democracy returned to Nigeria in 1999, expectations were high. The prevailing attitude among the citizenry was positive; the feeling was simply, "Hurray! We are free! We can do what we like." Many believed it meant that the government would provide everything. Others thought it meant that the country's struggling economy would finally improve. However, today, the average Nigerian encounters numbing frustration, disillusionment and psycho-moral dislocation owing to the failure of government to deliver the expected fruits of democratic governance. There's still unemployment, increased level of poverty, corruption and injustice in the distribution of the nation's resources thereby creating disunity among the divergent ethnic nationalities.

The opening up of the political space by the return to democracy has not only raised the hopes of those groups that had been hitherto marginalized or repressed, but also paradoxically raised the stakes in the competition for access to power and resources. Demands for inclusion have been strident, while the politics of exclusion has also been vicious- both reactions to and legacies of the long years of military dictatorship and the militarization of politics, as power controlled by the "few" remains the only gateway to the good life. 
In the midst of these struggles, the Nigerian state has been engaged in an economic reform programme based on economic liberalization, privatization, deregulation of the downstream sector of the petroleum industry, including removal of "subsidies" on petroleum products, civil service reforms, and an anti-corruption drive. A lot of effort has been deployed in attracting foreign investments alongside the reduction of the role of the state in the economy. However, Nigeria's transition from a state-led to a market-led economy has not been altogether unproblematic.

At the heart of the problems lie several issues: the increased dominance of the policy process by the international donor community and the Bretton Woods Institutions, the IMF and the World Bank, the new structure of ownership of privatized erstwhile state enterprises and interests, and the harsh social consequences of the economic reform project against a background of two decades of adjustment, widespread poverty and the near collapse of social infrastructure, including the educational and health sectors. As a result, there has been some resistance from civil society, particularly the labour unions, human rights groups and the press to reforms that are punishing the poor. Of note is the crisis surrounding the pricing of petroleum products, following the collapse of Nigeria's four refineries due to years of mismanagement, and the importation of refined products in spite of the fact that Nigeria is Africa's largest petroleum exporter.

Getting democracy to work in Nigeria, however, will require more than just reforming elections or government institutions. A problem that has mounted over 35 or 45 years will not go away in one day. Instead, solving the problem of democracy in Nigeria will depend far more on transforming citizens than reforming political leaders or government institutions. Therefore, the stakes in ensuring that Nigeria gets its democratic calculations right this time cannot be overemphasized. It is in the context of the foregoing, that recent trends in Nigeria shall be examined. But before that is done, what is democracy and National integration?

What does the foregoing portend for Nigeria's democracy? I-low can a heterogeneous and culturally diverse Nigeria begin to tackle these complex, hydraheaded problems in ways that strengthen democracy? In spite of having passed the post-transition election test, Nigeria's democracy is still on trial. This trial started long ago but the attention of the chapter is on the most recent phase of the quest for democracy in Nigeria for a practical and sustainable national integration for greater development. The emphasis is also on the content of democratic politics rather than its form, and the reality that democracy in Nigeria is still a contested terrain rather than a settled matter. It is these contestations between forces seeking to advance democracy, and those seeking to either subvert, or divert it to narrow opportunistic 
and hegemonic ends that define the very substance of the travails of democracy in Nigeria.

\section{Concept of Democracy and National Integration}

The paper is based on the theoretical premise that there are two main types of nation-states in the world (Iwara, 2004). The first are the ethnically and culturally complex states called 'political states'. The second types are the ethnically and culturally homogenous states. They are perceived as culturally homogenous because they possess their own distinct language, way of life and homeland. They are also known as 'cultural nations'. Historical evidence reveals that states that are largely composed of clearly distinct peoples adopt a federal constitution in recognition of their diverse and complex components, while culturally homogenous nations largely adopt a unitary constitution.

A cultural nation typically 'arrogates to itself the power of the kinship myth portraying the whole society as an ethnic community and demanding the allegiance of its people in ways that echo the imperative of ethnic loyalty (Iwara: 23). In this way, the nation is depicted as offering identity, security and authority to its members. In return, the nation demands the loyalty and allegiance of its members.

However, some states which possess a certain degree of cultural plurality choose to run their nation along lines of cultural nationalism. This is because they are convinced that cultural nationalism offers a stronger basis for national integration, political cohesion and societal loyalty than political nationalism. This may also derive from the fact that political nationalism is sometimes perceived by the elites as both Western and colonialist in connotation (Iwara: 23). When federalism is considered forced, as is the case with Nigeria, national integration becomes a major problem in the nation-building process, with components seeking greater autonomy of action and self expression as with the Niger Delta before now.

Also, some political states like Nigeria, despite their ethnic and cultural complexity, seek to portray their societies as potentially culturally homogenous. On the premise of their pre-colonial history, they promote a set of dominant cultural attributes and values around which nationhood is encouraged to evolve. Constitutional measures are also designed to assure the groups that feel threatened or marginalized within the federal state. Nationhood is therefore defined in terms of the equal rights, duties and status of all citizens. Ethnicity is thus portrayed as being politically irrelevant to the national politics of meritocratic governmental processes. It is on this premise that Iwara contends that:

The political state is then poised to accommodate the idea of a community comprising ethnic components or geographical zones, as in the case of Nigeria, with each component enjoying equal status, 
power and access to resources according to some formula of 'unity in diversity' (Iwara: 24).

Ordinarily, nations are expected to express themselves in a manner to typify any one category of nation-state. The empirical evidence from Nigeria suggests that it seeks to employ both formulations. For instance, while it claims to offer equal citizenship rights to all citizens irrespective of their cultural and numerical attributes, it, at the same time, defines the nation in cultural terms and gives priority of some kind to the major ethnic groups over the minority groups. Consequently, it is argued that where equal consideration is expected in an avowedly ethnically and regionally neutral meritocracy, what obtains is discrimination against some groups. This attracts varying degrees of resentment against the state, thereby undermining ethnic relations and national integration.

It is on this note that it has been argued that it is not entirely surprising that the nation has witnessed a series of successive ethnic rivalries which challenges the national integration efforts of the federal state. Rather, it is argued that as long as the Nigerian elites continue to comport themselves in this contradictory way, so long will ethno-regional groups such as Arewa Peoples Congress (APC), O'odua Peoples Congress (OPC), Ohaneze Ndigbo, Ijaw Youth Movement, Movement for the Actualization of the Sovereign State of Biafra (MASSOB), Movement for the Survival of the Ogoni People (MOSOP), Movement for the Emancipation of the Niger Delta (MEND), and Egbesu, continue to find popular support and blossom in the country (Olu Adeyemi (2007).

Democracy is a form of government, in which the supreme power of a political community rests on popular sovereignty. According to Oyovbaire (1987) democracy is a system of government which seeks to realize a generally recognized common good through collective initiation, and discussion of policy questions concerning public affairs and which delegates authority to agents to implement the broad decisions made by the people through majority vote.

As a principle of governance, democracy has been examined in both classical and contemporary contexts. In classical context, democracy is linked with the small city state of Athens in Greece, where all adjudged male adult citizens were allowed to directly participate in decision-making and implementation. Political philosophers articulated this form of democracy as a revolutionary antidote to dictatorship, monarchy, oligarchy, aristocracy and feudalism (Isekhure 1992). However, with the growing complexity of modern states in terms of vast territory and population, the classical democracy has become infeasible. Thus, in contemporary times, democracy has been referred to as the expression of popular will of the political community through elected representatives. The contemporary democracy according to Raphael (1976) rests on "representative government." Here the ordinary citizen comes into the 
process only by casting vote in the favour of a representative or broad policy of a party.

In contemporary times, democracy has remained the most preferred form of government. The major hallmarks of democracy include popular participation, supremacy of majority will but with respect for minority rights, constitution of government by popular choices through periodic election, competition for public office, freedom of the press and association, incorruptible judiciary, respect for the rule of law, open and accountable government, and existence of competing political parties whose programmes and candidates provide alternatives for voters. As a form of government, democracy appeals to both the government and the governed alike. First, it assures equality by opposing discriminatory practices and abuse of power. Also, it assures individual liberties through constitutional safeguards such as freedom of association and free press. Furthermore, it guarantees popular participation in government.

The above values of democracy are difficult to entrench. Granted that democracy cannot be regarded as a perfect system, it remains the most cherished form of government in the world today. It still offers better prospects and kindles greater hopes than any other form of government in the contemporary world. The elements of democracy are fundamental requirements necessary for effective governance.

For the success of democracy in practice, the people must desire it and be prepared to work for it and make necessary sacrifice for it. There must be tolerance for opposing views, rationality, and openness and no dogmatism, militarism or authoritarian tradition. The leadership must be comprised by men and women of unimpeachable character and outstanding initiative rather than those lacking sense of responsibility, moral value and self enlightenment (Agarwal, et al. 1994).

\section{Recent Trends in Nigerian Democracy and the Implications for National Integration}

Evaluating the trend line of Nigerian democracy requires a critical yet realistic perspective about the many barriers confronting Nigerian democrats. Indeed, in addition to overcoming the authoritarian legacies of colonial and military rule, the enormous size, ethnic diversity, and political complexity of Nigeria would daunt even the most talented and committed democratic reformers. When compared against perilous situations of neighbouring states (e.g. Ivory Coast, Chad, Sudan, Congo), the fact that Nigeria survives as a united, democratic nation-state is no mean achievement and should be a cause for celebration. Realistically, however, institutionalizing full democratic processes in Nigeria for national integration is very likely to be a multigenerational undertaking. 
Authoritarian rule by an institutionalized oligarchy constitutes the main structural obstacle to deepening democratic rule in Nigeria. The oligarchs are composed of self- serving politicians, businesspersons, political fixers, 'godfathers," former military officers, and elite bureaucrats who share a common interest in sustaining oligarchic power. Even though the oligarchy claims to represent democratically based regional, professional, and ethnic constituencies, its record falls far short of its claims, Constitutional provisions, state centralization, and accumulate ted political experience have nurtured far greater national integration within the oligarchy than among the fragmented groups that they rule. Informal networks of power based upon friendships, pragmatic alliances, financial deals, monopolizing information, and, above all, the patrimonial distribution of patronage sustains and reproduces the ruling oligarchy. To maintain power, the oligarchs trade offices; coop rivals, distribute concessions and contacts; and bleed the public treasury to fund their private fortunes, clients, political parties, and political thugs. Unable to show how their salaries could explain their life-styles, fortunes, and patronage, they have institutionalized a political order indifferent to legal, ethical, or even communal accountability.

It would appear that since the return of democracy, Nigeria has witnessed an escalation of violent and disintegrative conflict. The struggles are driven by the quest to fill the power vacuum left by the retreating military, but more fundamentally, the contestations between various groups in a context of rising demands relative to shrinking scarce resources. These conflicts have largely been identity driven: communal, ethnic and religious. The "we" against "them", "indigenes" versus "settlers" and "insiders" versus "outsiders" relations of inclusion/exclusion have been continuously mobilized and deployed in the rivalries and violent struggles for access to power and resources. The whole issue of political space in the sense of exclusive control and rights within a claimed territory, to the exclusion of "others", has been a distinct feature of the unfolding crises. The process of discriminating against or excluding "other" Nigerian citizens on the basis of their being "non-indigenes" or belonging to "other" religions or "other" communities can be deduced from conflicts that have ravaged the Northern and Central parts of Nigeria, as well as the oil rich Niger Delta region where before now violence reached alarming levels.

In all these conflicts many lives have been lost, people have had their properties destroyed and some have been displaced as a result. Worse, the unity of the country and its very basis are being dangerously eroded in the face of the inability of the fledgling democratic institutions to effectively mediate the spiralling violence. What can be seen is the use of security forces or the military to quell these conflicts, even when the political options have not been exhausted or the roots of conflict especially absence of human security addressed (Agbaje, 2011).

Copyright $(\mathrm{C}$ IAARR, 2015: www.afrrevjo.net

Indexed African Journals Online: www.ajol.info 
Since 2000, Nigeria has witnessed various dimensions of political, economic and social crises. In the run up to the 2003 elections and after the elections, violent conflicts, involving the ruling party and other parties engaged in the struggle for power created a lot of tensions. This was against the background of the crises following the adoption of Sharia Islamic law by most states in northern Nigeria, communal conflicts in central Nigeria, the abduction of a sitting governor in Anambra state, and a couple of unsolved high profile political murders, including that of the Minister for Justice and Attorney General of the federation. The system was also overheated by the declaration of a State of Emergency and the suspension of democratic institutions in Plateau state, and the appointment of a retired general as the sole administrator for the state by the President before seeking and obtaining the approval of the National Assembly. Escalating violence in the northeast, involving heavily armed youth militia, or criminal elements and the charge by the opposition parties and human rights groups that Nigeria is gradually becoming a one party state do not help the situation.

Nigeria's great cultural diversity, however, is not in itself the reason why consensus and nation unity remains elusive. Class differences between the few rich (of all ethnicities) and the masses of the poor create an environment in which culturebased competition flourishes. Grinding poverty amidst a centralized, oil-dependent economy, combined with the centralization of political power in the hands of the executive, exacerbate cultural differences and promote intense political competition. This economic and political centralization promotes a zero- sum perspective on politics that deepens the divisions among Nigerians. This makes it harder to achieve consensus on issues of common good and the nation-state aspirations for a United Nigeria.

One bright spot, however, is that Nigerians appear to have come to consensus that democracy is the only acceptable political alternative for the nation to achieve ethnic/national integration for equitable development. This commitment to democracy remains despite widespread frustrations that the government has yet to produce a satisfying "democracy dividend." Moreover, although public confidence in democracy suffered after the deeply flawed since 1999 elections, inter-ethnic competition has generally not resulted in widespread calls for separation from Nigeria. Rather, elites have focused their sectional concerns toward more negotiable goals of restructuring the federation and the formulae for passing out oil profits.

The key issue of federalism has been at the heart of the struggle for consensus. Getting this right has historically been the most difficult stumbling block to national unity/integration. Nigeria has had four constitutions since independence (1963, 1979, 1989, and 1999), reflecting an ongoing debate over the allocation of political power and government resources. The state and local governments are 
dependent on federal government transfers for 70-80 percent of their revenues, and resources are allocated according to federal criteria. As the number of claimants on the system has multiplied, so have the number of states and LGAs. Nigerian federalism thus has evolved in a manner which has less to do with ensuring the autonomy of its component states and localities, and more with the elaborate distribution of federal largesse downwards. Likewise, the current constitution also indicates that the public political positions be allocated according to the federal character principle, as enshrined by Article 14(3) and monitored by the Federal Character Commission (FCC).

Since 1999, Nigeria has not yet transited to a legal system or political culture that can be described as fully democratic. A disconnect between the legal and political processes has been a direct consequence of the military's approach to governance. The result has been citizens being subject to arbitrary government decisions. In the absence of effective legal recourse, citizens rely on their personal contacts and networks with elites or influential government officials. To move away from the extra-judicial means of pressing for political demands will require a different orientation towards respecting the rule of law regardless of who is in power.

One disturbing development undermining the rule of law and building on the old authoritarian patterns, however, is the rise of ethnic-based militias across several sections of the country. Gangs of armed youths purporting to protect the interests of the Yoruba, Igbo, Ijaw, Hausa, or other groups have been active in various capacities over the past couple years. The most notorious of these has been the Boko Haram Boys, operating in the northeast, but there have also been much smaller and more localized groups springing up. Politicians have shown increasing willingness to rely on these militias for political vendettas and election related intimidation tactics.

There have been some unimpressive efforts also at police reform to date, with one of the principal obstacles to greater accountability being the fact that the police are not answerable to state or local authorities. For example, there are now human rights desks in many police stations, but there are no community oversight boards, whereas historically, policing methods were rooted in the community, and closely interlinked with social and religious structures. As with other public goods and services, the state has largely failed to provide effective personal security or access to justice for its citizens making it very difficult for the people to think about national integration.

Unlike other developing democracies, the members of Nigeria's large professional associations-law, medicine, unions, accountants, academics, and womenhave not provided leadership for opposition political parties. As a result, they have not yet been able to mount an effective oppositional movement. Civil society groups are numerous and active but they are fragmented, local, and not yet integrated into 
strong, cohesive national organizations. Hence, without effective political parties, their opposition and reform programs are often frustrated by the entrenched elite. In short, there is a disconnect between an elite that struggles to maintain its relative hegemony and the bulk of the population who find themselves disenfranchised by the informal patterns of patrimonial power that characterize public decision making in Nigeria.

Furthermore, competition between branches of government and between levels of government also remains weak. The executive has overriding power compared to the other branches of government, and it controls the financial autonomy of the other branches. The executive often determines the leadership of the National Assembly, as do the state governors in regards to the state legislatures. Neither the civil service nor the judiciary is typically powerful or impartial enough to act as an effective constraint on the power of the executive, although the federal judiciary has shown itself to be an increasingly important check.

Likewise, the relations between federal, state, and local governments are also top-down, both in terms of revenues and the authoritative use of force. States do not have their own independent tax bases or independent police. Rather, the relationship between states and the federal government has in this regard become more centralized over time since, under the Independence Constitution and the subsequent Republican Constitution adopted in 1963, the regions enjoyed greater power over the police. Several governors, however, have been reined in more recently when they sought to establish independent police forces. Under President Obasanjo, the police have gone from 150,000 to over 300,000 strong.

Politics in Nigeria is still largely an elite game, along the lines presented above: rich, male, and old. This closed system is propagated by what Nigerians refer to as the "sit tight" or incumbency syndrome, in which elected officers refuse to relinquish their seats in government despite their poor performance, and utilize any means to stay in office. Not only does this result in an inadequate circulation of elites, but it also perpetuate systematic discrimination against three primary groups: Women, the poor, and non-indigenes.

Another key barrier to integration in Nigeria's democracy is the widespread discrimination against citizens known as no indigenes, no matter how strong their ties to the communities in which they live. All Nigerians are officially classified into two types of citizens: those who can trace their ethnic and genealogical roots back to the people who are said to have originally settled there (indigenes), and those whose ancestors came from elsewhere. There is no way for a non-indigene to become an indigene, no matter how strong or long-lasting the ties to the communities in which they are resident. As a matter of policy, many states refuse to employ non-indigenes in the civil service and exclude them from academic scholarships. The rights that are 
systematically denied to non-indigenes run directly counter to the constitution's guarantee of freedom against, discrimination, and remain a source of considerable resentment questions about national integration among many Nigerians, especially as demographic changes in the country continue to take place, such as internal migration.

Corruption is still the stock-in-trade of Nigerian democracy, rooted in the centralized, clientelistic nature of politics described above. Political elites misappropriate considerable public funds for their personal gain, while most of their constituents lack access to potable water and many other socio-economic infrastructures and services. There is a big problem with the wage structure of the bloated civil service (not to mention not being paid on time), which is filled with patronage hires. Consequently, many Nigerians are forced to resort to petty corruption simply to survive. The key to cementing the country's patronage system through corrupt procurements is the handing out of government contracts to political favourites. This has been the case for contracts for building roads, schools, hospitals, and for the supply of electricity, water, and medicines, etc. Nigeria was ranked as the most corrupt place on earth in 2003, but its relative ranking has since been upgraded to 152 nd out of 159 countries.

As good governance continues to he found lacking by the majority of Nigerians who live without access to basic public services, other organizations have stepped in to fill the void. Religious organizations, such as the Pentecostal churches, now provide a range of social services that government generally provides, and Islamic religious schools have also sprung up in the north. This has actually provided some promising new means to try to address the potential for inter-communal conflict, whereby inter-faith organizations have been offering means for dialogue between groups. Similarly, women's groups fighting AIDS, for example, have used faith-based leaders (both imams and priests) to try to mobilize communities around public health issues.

The above analysis of democratic governance in Nigeria indicates that there are severe problems in the area of national integration for equitable national development which highlight the ongoing need to establish a social contract that encompasses both the informal and formal exercise of power. Rule of law in Nigeria has been constrained by a military legacy of authoritarian centralism that has been distorted and rendered less accountable by access to massive petro-rents that have fueled patronage systems. In the area of competition, meaningful representation has been hampered both by flawed electoral processes and inadequate political parties that lack mass appeal. Focusing on the dimension of inclusion highlights the failure of the Nigerian state to give priority to responding to the needs of the poor and the youth and also points to the need to remedy entrenched patterns of discrimination that 
affect the non-indigenes and women. The governance dimension continues to be dominated by the ramifications of corruption and the difficulties in eradicating what has become a part of the system itself.

These problems are symptomatic of a broader, overarching democratic governance problem in Nigeria, which relates to an oligarchic control of political power, both formal and informal, by unaccountable political elites. This oligarchic control of political power contributes to patterns of inefficient centralization, a dearth of meaningful representation within the political system, and a culture of impunity that dates back to military rule. This has created a stark gap between the rulers and the ruled, leading to a general dissatisfaction and cynicism regarding governance combined with growing sentiments of injustice which are fuelled by attempts to manipulate ethno-religious rivalries. This directly threatens political stability, which is extraordinarily fragile. A breakdown in stability could undermine ongoing for national integration.

\section{Integration Mechanisms Adopted by Nigerian Governments towards National Integration}

The constitution: As an integrative measure, the federal government abolished the regional constitutions and evolved a single document for the whole country. Equally, several provisions were enshrined in all the constitutions adopted thereafter including the current 1999 constitution, such as articles that are expected to promote national integration.

Federalism: Federalism is a system in which government powers that exist in a state are shared constitutionally between the central authority and that of the component or federating units. Through this, the concept of national integration is given expression. As opined by Obafemi Awolowo, "if a country is bilingual or multilingual, the constitution must be federal and the constituent states must be organized on linguistic basis". He goes further to stress that "only a truly federal constitution can unite Nigeria and generate harmony amongst its diverse racial and linguistic groups (Fagbamigbe, 1981: 4-5). Basically, the amalgamation of the North and South in 1914 laid the historical foundation for federalism in Nigeria and the outcomes of constitutional conferences agreed on the use of federalism as an ideal system for the country.

National Anthem: A national anthem is intended to evoke a feeling of patriotism and make people of that country work for the progress, unity and growth of the country. Usually it contains the ideals and traits which the country intends to impart to its citizens. The national Pledge is regarded as an oath of citizenship with promises to the country. It is intended to help citizens to growth to love to love and serve their country and reminds them of other responsibilities to the country. 
Revenue Allocation: To further strengthen national integration, revenues which are generated are pooled into a common fund, and shared thereafter to all tiers of government using agreed parameters (see Section 162 (2) of the 1999 Constitution).

Establishment of Political Parties: Ethnically based political parties were known to be harbinger of distrust and violence. To avoid this, and encourage national integration section 222 (b) of the 1999 Constitution slates: "The members of the association are open to every citizen of Nigeria irrespective of his place of origin, circumstance of birth, sex, religion or ethnic group". Also section 223 (2b) of the said constitution states that "the members of the executive committee or other governing body of the political party shall be deemed to reflect the federal character of Nigeria".

Federal Character Principle: This is a strategy adopted by the government at all levels to ensure equal distribution of scarce resources to all diverse groups that make up Nigeria, sl that no group dominates and controls the resources to the detriment of the others. Consequently, appointments, siting of industries, schools and provision of social amenities, etc are made in a way to allow every group to participate in the system. The central philosophy is to diffuse primordial sentiments, create an enabling environment for peaceful co-existence and engineer the process of national integration (Okibe, 2000: 194). As expressed in the moribund 1979 Constitution, the federal character principle states:

The composition of the government of the federation or any of its agencies be carried out in such manner as to reflect the federal character of Nigeria and the need to promote national unity and also to command loyalty thereby ensuring that there shall be no predominance of persons from a few states or form a few ethnic or other sectional groups in that government or any of its agencies (Section 14 (3) of the 1979 Constitution).

Equally, the 1979 Constitution (and the 1999 Constitution) enjoins that the affairs of the central, state, local government areas, government parastatals, etc. shall be carried out in such manner as to recognize the diversity of the peoples within its area of authority with the over-riding intention to unite and integrate them.

State Creation: Decree No.14 of 1967 introduced by the Gen. Yakubu Gowon's regime created twelve states in Nigeria on May 27, 1967: six in the north and six in the south. This move was made to satisfy the yearnings of Nigerians for state creation since colonial times. The government equally felt that such decision will help strengthen national unity. Along this trend, by 2009, the numbers of states have risen to thirty-six with the tendency of increasing further.

Rotational Presidency and Rotation of Power: In its strong and determined desire to further strengthen the spirit of national unity, the still-born Gen. Sani 
Abacha's 1995 constitution in section 229 (4), made provision for rotational presidency and rotation of power between the six geopolitical zones, as in:

1- North-Central: Benue, Kogi, Kwara, Nasarawa, Niger, Plateau and FCT

2- North-Eastern: Adamawa, Bauchi, Borno, Gombe, Taraba and Yobe

3- North-Western: Jigawa, Kaduna, Kano, Katsina, Kebbi, Sokoto and Zamfara

4- South-Eastern: Abia, Anambra, Ebonyi, Enugu and Imo

5- South-South: Akwa Ibom, Bayelsa, Cross-River, Delta, Edo and Rivers

6- South-Western: Ekiti, Lagos, Ogun, Ondo, Osun and Oyo

\section{What Nigerian Democracy should Strengthen for National Integration}

In June 2007, a few weeks after the inauguration of President Umaru Yar'Adua Administration, I surmised as follows in a paper presented in Germany:

...the following are the major tasks ahead, which the new presidency must tackle in order to reposition and fast- track Nigeria towards stable socio-economic and democratic development:

1. The major task of restoring hope in transition to democracy: Be back 'on the road again' to be achieved through:

- Reforming the electoral and party systems

- Strengthening constitutionalism and Rule of Law

- Promoting and protecting the rights and freedoms of the people

- Initiating a credible process of constitutional review to deal with the most glaring weaknesses/ deficiencies of the 1999 Constitution, such as concentration of powers and resources in the federal government at the expense of state governments.

- Promoting good, democratic governance; curbing prebendalism and patrimonialism in government.

2. Reviving and strengthening institutions

- Reforming the bureaucracy

- Engendering a competent and efficient technocracy

- Reforming police and security agencies

- Further reforming and strengthening the judiciary

3. Addressing, concrete1, the fundamental needs and aspirations of the people

- Reviving economy

- Creating/providing jobs

- Addressing youth unemployment and restlessness

- Investing adequately in education/human capital development

- Facilitating rural and Community development

4. Reconstructing infrastructure and facilities

- Focusing and placing priority on power generation and distribution 
- Rehabilitating and expanding roads and highways

5. Fighting corruption

- Arresting partisanship and vindictiveness in the fight against corruption

- Broadening the scope of the fight against corruption and targeting local governance

- Setting real examples

6. Broadening popular participation in governance

- Promoting inclusiveness rather than exclusion

- Expanding the scope of, and further democratizing, local governance

One of the main challenges confronting the Nigerian transition to democracy is how to make participation broadly inclusive; that is, how to give marginalized groups a say, a sense of belonging. For decades under military rule, the political space was very narrow and relatively exclusive. Although the military handed over power to civilians in May 1999, for eight years the political space has bard been opened up. Deep-seated legacies of authoritarian military rule obstructed the rule of law and due process. By the time of the April 2007 elections, there was heightened anxiety and concern about the sustainability of the democratic transition, given its thrusts and direction. Undemocratic, repressive and exclusionary tendencies and practices characterized the whale processes in the preparations leading to the elections. A major task ahead of the new government therefore, is to broaden popular participation in governance and promote inclusiveness rather than exclusion. Disadvantaged and marginalized groups need to be given a voice and brought on board. Legacies of military authoritarian rule need to the systematically dismantled" (Jega, 2007b).

\section{The Way Forward}

This paper has only attempted to give an overview of the situation in Nigeria in the last ten years. It has not been able to detail the performance or otherwise of the democratic experience in all these years in quantitative terms. But one thing that must he exposed in terms of assessing whether democracy has been able to enhance National Integration is to understand the basic problem which has already been highlighted as the inability of the political elites to understand and manage the system they are operating. Jega (2004:11) alluded to this when he observed that:

The inadequacy of the ruling class, in terms of lack of vision, competence, intellectual ability, democratic credentials and integrity, further complicates the situation in the sense that elected leaders have become patently incapable of addressing the economic crises and the perpetual instability in the system. They simply act like the proverbial ostrich, oblivious of what is happening around them, and 
busily engaged in graft and the advancement of selfish and parochial interests (Jega, 2004:11).

Thus, the first and foremost solution to the problem of democratic development is to develop a leadership that is intellectually sound, that is disposed to the knowledge of the socio-political and economic attributes of the nation, not the and visionless types that have ruled the country over the years and have squandered the enormous resources of the country. The country needs a leadership that must have national acceptance and one that must appeal to an undifferentiated public. Such leaders must mould around themselves the basic characteristics of charisrnaticism that would enable them to be national as against the regional or ethnic-based leadership that has been recruited for the country over the years.

Nigeria needs to look more inwards in the sense that it should create an ideology of development that is derived from its socio-political and economic horizons. Colonialism created for Nigeria a peripheral position in the international system of capitalism which till today has not given the country any direction for an ideological mould that would integrate and unify the country toward a socio-political and economic order. The dynamics of the foundations that colonialism laid for Nigeria and the crises of development that followed the early years of independence created a situation of lawlessness, irresponsibility unaccountability and waywardness which are antithetical to progressive ideological development. Till date, Nigeria continues to be set adrift and like a ship without a captain, the country has been floating aimlessly. When Murtala and Buhari, both of whom never professed to be revolutionary came on board, the country temporarily sat up. But neither of them had a coherently formulated ideology of transformative governance. After them Nigeria went back to oblivion and has continued to sleep without waking up.

Since the capitalist ideology emphasizes individualism and maximization of profit through the exploitation of labour, the peripheral capitalism that Nigeria seems to be following has continued to formulate strategies through which primitive accum1atjon and capital flight continue to persevere. Currently, that has been part of the privatization policy of the present democratic set up.

The two prominent that Nigeria has used, the 7979 and 7999 constitutions are a reflection of the above tendency. Both constitution from their provisions show the obvious desire and will to maintain the existing pattern of economic activities imposed on the country. As this writer (Okpaga, 2008) recently observed, there has not been any attempt to question the continuation of the inherited import export economy. The inherited social formulations arising from the colonial and neocolonial modes of production have not been tempered with. That is why the political process, for example, in terms of parliamentary constituencies still run along geographical lines rather than the lines of relations of production, the roles that 
individuals and groups play in the production process. These processes have cumulatively led to a situation where political leaders and those in positions of power and wealth see the state as a barbecue out of which anyone with a knife can cut as much part as possible for himself and his sections. This tendency has obviously bred corruption, irresponsibility and lawlessness on the part of those who hold the reins of power at whatever level in the country.

What the country needs in this current democratic experiment is a new direction that must be completely divorced from its erstwhile colonial orientation if it must chart an appropriate course of development. Since 1999 Nigeria has operated a constitution and a system that is largely encouraging of lawlessness, irresponsibility, greed, lack of accountability and transparency among other ills. The level of poverty, ignorance and disease is a pointer to the unfavourable conditions of life for the majority of the populace. All these are the consequences of the adoption of the British capitalist parliamentary and the American presidential systems, and the acceptance of the dictates of the international financial institutions and their sponsors.

A government that encourages exploitation of its people by its people through the concept of 'democracy of government of their people for their people and by their people' and of those who have over those who do not have, is not one that is responsible to the people as the principles of democracy provide. Nigeria needs a government that is disposed to good governance which can provide the essentials of development. Development must he rooted in the people who are the promoters of democracy.

The challenge of today is that of encouraging good governance It is due to the lack of this that the last ten years have been a ding-dong affair. Nigerian leaders must learn lessons from their previous experience and those of other countries that are progressing. Nearby are Ghana and South Africa that have used their leadership to promote Socio-economic development Nigerian politicians should not see politics as a 'do or die' affair as the elections in Nigeria have become.

If Nigeria is running a democratic system of government that is expected to promote democratic values of public accountability, transparency, good governance good conscience, fiscal discipline, due process etc, it should create more credible mechanisms for enforcing these values of democracy. A framework of political participation through economic enhancement should be created. This would re-direct Nigerians toward national economic and political life. There should also be a complete re-evaluation of Nigeria's national polity in its relations with the global financial or capital system and the tendency toward adopting a government system that is Strange to the conditions of its people. It is the lack of the uflderstaidin1y of the imported structures of politics and economics that has created the tendency of crises in the country today. There is thus, the need for the new democratic system to 
forge appropliate strategies to enhance the tenets of democratic development. It is not vision 2010, 2020 and 7-Point Agenda that is the remedy. The solution is to develop issues that would lead to the development of the people; reduce poverty, promote equality in the distribution of national resources and leadership of the majority of the people of Nigeria.

\section{Conclusion}

There can be no easy answers, and the solutions will be difficult. A modest point to start from is for those running Nigeria's democracy to implement socially just and welfarist policies based on a new social contract that will ease the pains of the people and for the forces of economic globalization to take into consideration that more than two decades of adjustment in Nigeria have failed to deliver development to the people. What perhaps is needed is less, not more, of the same. A new democracy from below, rooted in the people and a developmental state, representing and reflecting their quest for dignity, equity, welfare and freedom offers brighter prospects. Whose democracy will survive without a united people? That is a question that time and the outcome of the ongoing struggles in Nigeria will ultimately answer.

The pressure is mounting for visible progress in institutionalizing democratic reform and inculcating the idea of national integration, because the profound insecurity inherent in the present system virtually guarantees declines in living standards, rising inequality, increasing political violence and other disintegrative vices.

\section{References}

Agarwal, N.N., Bhusan, V. \& Bhagwan, .V (1994). Principle of Political Science. New Delhi: R. Chand and Co.,

Aremu, Fatai A. \& Omotola, J. (2007). Violence as Threats to Democracy in Nigeria under the Fourth Republic, 1999-2005. African and Asian Studies, Vol. 6 Nos 1-2, 2007. Japan: BRILL.

Iwara A.U. (2004). Identity Politics, Globalization and Socio-Political Engineering in Nigeria. In Duro Oni et'al (eds.). Nigeria and Globalization. Discourses on Identity Politics and Social Conflicts. Lagos: Centre for Black and African Arts and Civilization (CBAAC) p.22.

Beetham, D. (1994). Defining and Measuring Democracy. London:Sage Publications.

Collier, Paul (2008). Wars, Guns and Votes: Democracy in Dangerous Places. UK: Oxford University Press.

Danapoulous, C.P. (1992). From Military to Civilian Rule, London: Routledge. 
Diamond, L., Lintz, J. \& Lipet, S.M. (eds.), (1990). Politics in Developing Countries: Comparing Experiences with Democracy. Boulder, Colorado: Lynne Riener.

Fagbamigbe, O. (1981). Voice of Courage-Selected Speeches of Chief Obafemi Awolowo. Vol. 2, Akure, Nigeria: Olaiya Fagbamigbe Publishers.

Isekhure, N. (1992). Democracy in Crisis (Edo State Election Tribunal in Perspective. Benin City: Jodah Publication.

Jega, A.M. (2007). Democracy, Good Governance and Development in Nigeria. Ibadan: Spectrum Bks. Ltd.

Jega, A.M. (2007b). Nigeria After the 2007 Election: The Tasks Ahead. Keynote Address Presented of the International Conference on the theme: Nigeria to Rich for Dignity and the Law? Held at the Evangelische Academic, Loccum, Germany 15 th -17 th June.

Jega, A.M. (2004). Democracy, Economic Crisis and Conflicts: A Review of the Nigerian Situation. The Quarterly Journal of Administration. Vol.xxxii, No.1. March.

Mimiko, N.O. (1995). Crisis and Contradictions in Nigeria's Democratization Programme.1986-1993, Stebak Books, Akure.

Ojo, Bamidele, A. (2001). Problems and Prospects of Sustaining Democracy in Nigeria. New York: Huntington.

Okibe, H.B. (2000). Political Evolution and Constitutional Development in Nigeria, 1861-1999. Enugu: Marydam Publishers.

Olu-Adeyemi, Lanre (2007). Ethno-Religious Conflicts and the Travails of National Integration in Nigeria's Fourth Republic. Accessed at www.dawodu.com.

Oyovbaire, S.E. (1987). Democratic Experiment in Nigeria. Benin City:Omega Publication Limited.

Raphael, D.D. (1976). Problems of Political Philosophy. London: Macmillan Press Ltd.

Rodoif, S. (1990). The Ethnic Question: Conflicts, Developments and Human Rights. Tokyo: UNO Press.

Rutham, J. (1992). From Confrontation to Cooperation: Resolving Ethnic and International Conflicts, London: Sage Publications.

Tilly, Charles (2007). Democracy. New York: Cambridge University Press. 